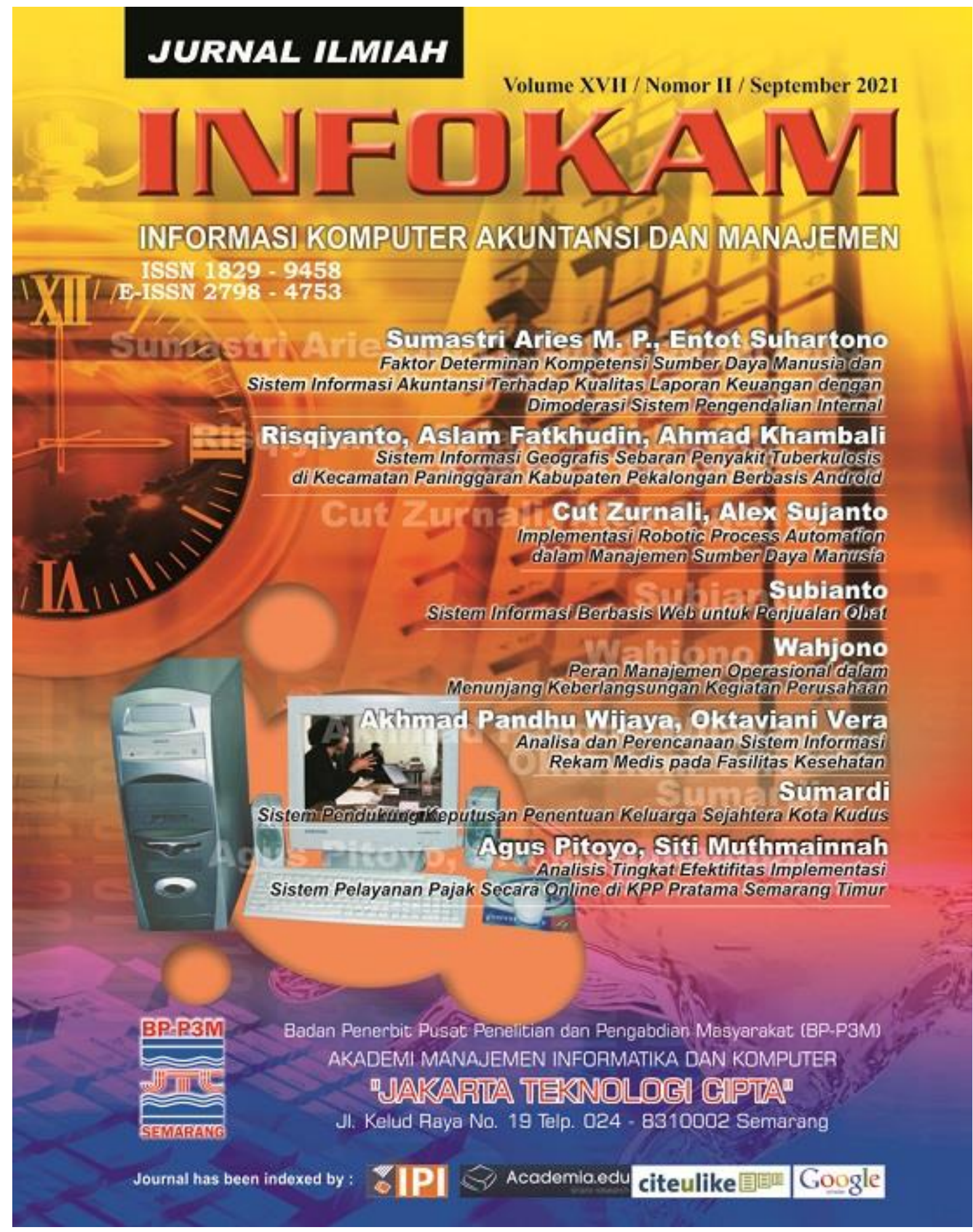


INFORMASI KOMPUTER AKUNTANSI DAN MANAJEMEN

ISSN 1829 - 9458

E-ISSN 2798 - 4753

SK DIREKTUR AMIK "JTC" SEMARANG

NO. 6305/AMIKJTC/D/IX/2020

Penasehat : Dr. Alex Sujanto, SE, S.Pd, MM. (Direktur)

Pengarah : Kristiawan Nugroho, M.Kom (Pudir I)

Muhamad Danuri, M.Kom (Pudir III)

Penanggung Jawab : Sumardi, S.Kom, M.Kom (Ka Progdi KA)

Subianto, S.Kom, M.Kom (Ka.Progdi MI)

Ketua Dewan Redaksi

Wahjono, SE, M.Si (Ketua Editor)

Sekretaris Editor

Anton Sujarwo, M.Si

Bendahara

Agus Pitoyo, M.Si

Anggota Dewan Editor

Subianto, M.Kom

Sumardi, M.Kom

Dr. Heru Sulistyo, SE, MSI ( STIE Dharmaputra Semarang)

Agus Prasetyo Utomo, MM., M.Kom (Univ. Stikubank Semarang)

Ira Setiawati, SE, M.Si (Univ. PGRI Semarang)

Eko Riyanto, S.Pd, M.Kom (STMIK Himsya Semarang)

Editor Teknis Dan Pelaksana

Sugeng Murdowo, S.T, S.Kom, M.Kom

Dr. Alex Sujanto, SE, S.Pd, MM

Mitra Bestari Peer Reviewer

Komputer

Daniel Alfa Puryanto, M.Kom (STMIK AKI Pati)

Aslam Fathkudin, M.Kom (Univ. Muh. Pekajangan Pekalongan)

Entot Suhartono, M.Kom (Univ. Dian Nuswantoro)

Fata Nida'ul Khasanah, M.Eng (Univ. Bhayangkara Jakarta Raya)

Noor Azizah, S.Kom, M.Kom (Univ. Islam Nahdatul Ulama Jepara)

\section{Akuntansi}

Dr. Heru Sulistiyo, M.Si, Akt (STIE Dharmaputra Semarang)

Arini Novandalina, M.Si (STIE Semarang)

Manajemen

Prof. Dr. Amron, SE. MM (Univ. Dian Nuswantoro Semarang)

Entot Suhartono, M. Kom (Univ. Dian Nuswantoro Semarang)

\section{Section Editor}

Subianto, S.Kom, M.Kom

Jurnal Ilmiah INFOKAM terbit minimal setiap 6 bulan sekali $(2 \mathrm{X}$ dalam setahun, bulan Maret \& September ) oleh AMIK "JTC" Semarang dengan maksud sebagai media informasi tentang Komputer, Akuntansi dan Manajemen bagi Sivitas Akademika pada khususnya dan masyarakat pada umumnya.

Alamat Redaksi / Penerbit :

Badan Penerbit Pusat Penelitian dan Pengabdian Masyarakat (BP-P3M)

AKADEMI MANAJEMEN INFORMATIKA DAN KOMPUTER

"JAKARTA TEKNOLOGI CIPTA"

Jl. Kelud Raya No. 19 Telp. 024 - 8310002 Semarang www.amikjtc.com/jurnal, email : infokam.amikjtc@gmail.com 


\section{INFORMASI KOMPUTER AKUNTANSI DAN MANAJEMEN \\ ISSN 1829 - 9458 \\ E-ISSN 2798 - 4753}

\section{DAFTAR ISI}

Faktor Determinan Kompetensi Sumber Daya Manusia dan Sistem Informasi Akuntansi Terhadap Kualitas Laporan Keuangan dengan Dimoderasi Sistem Pengendalian Internal

Sumastri Aries M. P., Entot Suhartono

Sistem Informasi Geografis Sebaran Penyakit Tuberkulosis di Kecamatan Paninggaran Kabupaten Pekalongan Berbasis Android

Risqiyanto, Aslam Fatkhudin, Ahmad Khambali

Implementasi Robotic Process Automation Dalam Manajemen Sumber Daya Manusia

Cut Zurnali, Alex Sujanto

Sistem Informasi Berbasis Web untuk Penjualan Obat

Subianto

Peran Manajemen Operasional dalam Menunjang Keberlangsungan Kegiatan Perusahaan

Wahjono

Analisa dan Perencanaan Sistem Informasi Rekam Medis pada Fasilitas Kesehatan

Akhmad Pandhu Wijaya, Oktaviani Vera

Sistem Pendukung Keputusan Penentuan Keluarga Sejahtera Kota Kudus Sumardi

Analisis Tingkat Efektifitas Implementasi Sistem Pelayanan Pajak Secara Online di KPP Pratama Semarang Timur Agus Pitoyo, Siti Muthmainnah 


\title{
Faktor Determinan Kompetensi Sumber Daya Manusia dan Sistem Informasi Akuntansi Terhadap Kualitas Laporan Keuangan dengan Dimoderasi Sistem Pengendalian Internal
}

\author{
Sumastri Aries M. P. ${ }^{1}$, Entot Suhartono ${ }^{2}$ \\ Email: 1 , 2 entot.suhartono@dsn.dinus.ac.id \\ Program Studi Akuntansi S1, Fakultas Ekonomi dan Bisnis \\ Universitas Dian Nuswantoro Semarang
}

\begin{abstract}
Abstrak
Kualitas laporan keuangan dapat dilihat melalui hasil audit. Laporan keuangan menjadi alat bagi investor untuk mengukur kinerja perusahaan yang dilakukan oleh jajaran manajemen, sehingga laporan keuangan yang disajikan harus berkualitas. Faktor-faktor yang mempengaruhi kualitas laporan keuangan adalah dengan penerapan sistem informasi akuntansi (SIA), kompetensi sumber daya manusia (SDM), dan penerapan sistem pengendalian internal (SPI) dilingkungan perusahaan atau organisasi. Tujuan penelitian ini adalah untuk mengetahui pengaruh penerapan SIA terhadap kualitas laporan keuangan, pengaruh kompetensi SDM terhadap kualitas laporan keuangan dimana SPI sebagai variabel moderasi. Objek penelitian adalah suatu perusahaan $X$ yang 3 tahun terakhir belum memiliki hasil opini audit Wajar Tanpa Pengecualian (WTP) dan yang dijadikan responden adalah karyawan bagian keuangan atau akuntansi sebanyak 450 orang. Hasil penelitian ini menunjukkan bahwa penerapan SIA dan kompetensi SDM berpengaruh terhadap kualitas laporan keuangan serta SPI mempengaruhi hubungan kompetensi SDM terhadap kualitas laporan keuangan. Namun SPI tidak mempengaruhi hubungan penerapan SIA terhadap kualitas laporan keuangan.
\end{abstract}

Kata Kunci: Kualitas Laporan Keuangan, Kompetensi SDM, Sistem Informasi Akuntansi, Sistem Pengendalian Internal

\begin{abstract}
The quality of financial reports can be seen through audit results. Financial statements are a tool for investors to measure the company's performance by management, so that the financial statements presented must be of high quality. Factors that affect the quality of financial reports are the application of accounting information systems (AIS), human resource competencies (HR), and the application of internal control systems (SPI) within the company or organization. The purpose of this study was to determine the effect of the application of AIS on the quality of financial reports, the influence of HR competence on the quality of financial reports in which SPI is the moderating variable. The object of this research is a company $X$ which in the last 3 years has not had an unqualified audit opinion (WTP) and the respondents are employees of the finance or accounting department as many as 450 people. The results of this study indicate that the application of AIS and HR competencies affect the quality of financial reports and SPI affects the relationship between $H R$ competencies and the quality of financial reports. However, SPI does not affect the relationship between the application of SIA to the quality of financial statements.
\end{abstract}

Keywords: Quality of Financial Reports, HR Competence, Accounting Information Systems, Internal Control Systems

\section{Pendahuluan}

Laporan keuangan yang berkualitas menurut Pernyataan Standar Akuntansi Keuangan (PSAK) 2015 Nomor 1 setidaknya memliki kriteria sebagai berikut: 1) mudah dipahami, 2). relevansi, 3) keandalan infromasi dan 4) dapat dibandingkan (Siregar, 2015). Laporan keuangan harus mudah dimengerti oleh para penggunanya dan tidak bias, laporan keuangan disajikan menggunakan standar berlaku. Laporan keuangan harus dapat menggambarkan kondisi keuangan perusahaaan dan sesuai dengan perkembangan. Laporan keuangan yang baik ialah yang memiliki nilai prediksi laba dan kinerja jangka panjang dan akan membantu manajemen dalam mengubah kebijakan tertentu. Kualitas laporan keuangan entitas bisnis 
dapat ditentukan dari hasil audit, semakin tinggi opini auditor maka berkualitas laporan keuangan yang disajikan (Djanegara, 2017). Hasil audit dapat dijadikan indikator pengukuran kualitas laporan keuangan, sehingga dapat dikatakan bahwa hasil audit yang baik, maka kualitas laporan keuangannya juga baik dan sebaliknya. Opini auditor independen ada 5 (lima) jenis yaitu Menurut (Syoftia dll, 2016),: 1) Wajar Tanpa Pengecualian (WTP), 2) Wajar Dengan Pengecualian (WDP), 3) Wajar Tanpa Pengecualian Dengan Penjelasan, 4) Tidak Wajar dan 5) Tidak Menyatakan Pendapat (Disclaimer).

Freeman (1983) pertama kali mengenalkan teori Stakeholder, yaitu teori yang menggambarkan kualitas suatu laporan keuangan. Fokus dari teori stakeholder bukan pada laba saja yang menjadi tujuan perusahaan, melainkan juga pemberian manfaat bagi para stakeholder (Maindaika, 2013). Teori ini menekankan bahwa sebagai entitas, perusahaan atau organisasi harus memberikan manfaat bagi stakeholder. Kelangsungan hidup perusahaan atau organisasi tergantung pada dukungan stakeholder, untuk memperoleh dukungan tersebut maka aktivitas perusahaan adalah untuk mencari dukungan tersebut (Hamdani, 2016).

Salah satu faktor determinan kualitas laporan keuangan pada penelitian Lestari dkk (2017) adalah kualitas sumber daya manusia (SDM) yang memiliki peran dalam penyusunan laporan keuangan, dimana semakin kompeten atau semakin baik kualitas sumber daya manusia yang terlibat maka akan semakin baik pula kualitas laporan keuangan yang dihasilkannya. Pada penelitian Putri dkk (2020) menambahkan faktor determinan kualitas laporan keuangan, yaitu penerapan sistem informasi akuntansi dan sistem pengendalian internal pada perusahaan. Sistem informasi akuntansi merupakan framework modern dalam pengelolaan aktivitas keuangan perusahaan yang menggabungkan sistem informasi akuntansi dan teknologi (Dita, 2016). Penerapan sistem informasi akuntansi akan membantu pihak manajemen dalam menyusun laporan keuangan berkualitas, dengan bantuan teknologi informasi akan mempermudah pihak manajemen dalam menyusun laporan keuangan berkualitas karena laporan keuangan yang dihasilkan lebih efisien dan valid. Penerapan SIA merupakan salah satu strategi perusahaan menghasilkan laporan keuangan berkualitas yang merupakan kepentingan dari stakeholder.

Kompetensi SDM merupakan salah satu faktor yang memberi pengaruh terhadap kualitas laporan keuangan. Kompetensi SDM merupakan suatu tingkat keterampilan atau kemampuan seseorang dalam melaksanakan fungsi-fungsi atau yang menjadi tugasnya untuk mencapai tujuan secara efektif dan efisien (Sudiarti, 2020). Kompetensi yang dimaksud adalah kemampuan untuk mencapai kinerja, untuk menghasilkan keluaran dan hasil sebagai sasaran aktivitas, dalam hal ini adalah menghasilkan laporan keuangan yang berkualitas. Sesuai dengan teori stakeholder, di mana pihak manajemen berusaha memenuhi kepentingan stakeholder dalam memperoleh laporan keuangan yang berkualitas dengan menyediakan sumber daya manusia yang berkualitas.

Sistem Pengendalian Internal merupakan kebijakan atau peraturan entitas mengenai prosedur aktivitas terstandar untuk memberikan jaminan layak bagi pihak manajemen dalam rangka mencapai visi misi dari entitas perusahaan. Sistem pengendalian interna/ terdiri dari unsur-unsur yang dijadikan pedoman atau peraturan penyelenggaraan serta tolok ukur pengujian tingkat efektivitas pengelolaan entitas perusahaan (Tawaqal, 2017). Sistem Pengendalian Internal (SPI) merupakan bentuk dari monitoring cost bagi prinsipal untuk mencapai kepentingannya dalam entitas perusahaan, dalam hal ini dengan adanya monitoring cost ini untuk memastikan entitas perusahaan menghasilkan laporan keuangan yang berkualitas.

Objek penelitian ini adalah entitas perusahaan X di Semarang yang dalam waktu 3 (tiga) tahun terakhir ini, yakni tahun 2017, 2018, dan 2019 hasil opini audit dari laporan keuangannya belum pernah memperoleh predikat Wajar Tanpa Pengecualian (WTP). Opini auditor Wajar Tanpa Pengecualian (WTP) merupakan hasil tertinggi dari proses audit dan mengindikasikan laporan keuangan entitas tersebut berkualitas dan sesuai dengan PSAK. Berdasarkan penjelasan latar belakang sebelumnya, maka penelitian ini bertujuan untuk mengetahui faktor determinan penerapan sistem informasi akuntansi dan kualitas sumber daya manusia terhadap kualitas laporan keuangan, serta tujuan penelitian lainnya adalah mengetahui faktor determinan sistem pengendalian internal mampu mempengaruhi penerapan sistem informasi akuntansi terhadap kualitas laporan keuangan, kemudian mengetahui faktor determinan sistem pengendalian internal mampu mempengaruhi kompetensi SDM terhadap kualitas laporan keuangan. 


\section{Landasan Teori}

\section{a. Teori Stakeholder}

Stakehoder merupakan pihak-pihak yang memiliki kepentingan pada perusahaan dan dapat memberikan pengaruh terhadap aktivitas perusahaan. Stakeholder yang dimaksud dalam hal ini adalah pihak dari masyarakat, karyawan, pemerintah, supplier, pasar modal, dan lain-lain. Entitas perusahaan tidak hanya beroperasi untuk kepentingan perusahaan itu sendiri tetapi juga harus memberikan manfaat bagi para stakeholder-nya (pemegang saham kreditor, konsumen, supplier, pemerintah, masyarakat, analis dan pihak lainnya). Keberadaan suatu entitas perusahaan dipengaruhi oleh dukungan yang diberikan oleh pihak stakeholder kepada entitas perusahaan tersebut (Rokhlinasari, 2015).

Teori stakeholder dikenalkan pertama kali oleh Freeman (1983), di mana yang menjadi latar belakang dari pendekatan teori ini adalah keinginan untuk membangun suatu framework yang bersifat responsif terhadap permasalahan yang dihadapi para manajer saat itu, di mana stakeholder sebagai setiap kelompok atau individu yang dapat dipengaruhi oleh pencapaian organisasi. Teori stakeholder menerangkan bagaimana entitas perusahaan memenuhi harapan pihak stakeholder. Pihak stakeholder memiliki hak yang sama dalam memperoleh informasi mengenai kondisi atau kinerja entitas perusahaan, di mana informasi tersebut digunakan untuk pengambilan keputusan (Hamdani, 2016).

Berdasarkan karakteristiknya stakeholder ada 2 macam, 1) stakeholder primer dan 2) stakeholder skunder (Munawarah, 2017). Stakeholder primer merupakan pihak-pihak individu atau kelompok yang paling berpengaruh langsung dalam perusahaan, seperti investor, pemegang saham, karyawan, pemasok, pelanggan, dan pemerintah. Sedangkan stakeholder sekunder yaitu pihak-pihak yang mempengaruhi atau dipengaruhi oleh perusahaan tetapi tidak terkait dengan transaksi perusahaan dan tidak begitu esensial keberadaannya.

Salah satu aspek penting yang mempengaruhi kelancaran hubungan antara entitas perusahaan dan stakeholder adalah kualitas laporan keuangan yang disajikan. Semakin baik kualitas laporan keuangan yang disajikan, semakin baik pula hubungan kedua belah pihak tersebut, karena meningkatnya rasa kepercayaan stakeholder pada entitas perusahaan (Hamdani, 2016).

\section{b. Kualitas Laporan Keuangan}

Peraturan Pemerintah Nomor 71 Tahun 2010 mengenai laporan keuangan adalah laporan terstruktur terkait dengan laporan posisi keuangan serta transaksi-transaksi yang telah dilakukan oleh suatu entitas perusahaan. Laporan keuangan merupakan media untuk mengkomunikasikan informasi keuangan utama kepada pihak-pihak di luar perusahaan (stakeholder). Laporan keuangan dapat didefinisikan sebagai media untuk menggambarkan kondisi keuangan dan hasil usaha yang ditujukan kepada pihak-pihak stakeholder. Informasi keuangan mengenai aktivitas ekonomi dalam suatu perusahaan tidak hanya dicatat dalam satu siklus akuntansi, tetapi juga diproses sedemikian rupa dan diringkas sehingga dapat memberikan informasi keuangan yang berkualitas untuk pengambilan keputusan (Inapty, 2016). Kualitas laporan keuangan yaitu bagaimana laporan keuangan disajikan menunjukan informasi yang berkualitas (benar dan jujur), di mana laporan keuangan tersebut digunakan oleh stakeholder dalam pengambilan keputusan (Sarwani, 2019).

Kualitas laporan keuangan idealnya mencerminkan gambaran yang akurat tentang kondisi keuangan dan kinerja entitas perusahaan. Laporan keuangan merupakan suatu laporan yang menunjukan tingkat keberhasilan perusahaan dalam menjalankan proses bisnisnya. Jika laporan keuangan yang dihasilkan oleh perusahaan berkualitas baik dapat dikatakan pihak manajemen perusahaan berhasil menjalankan proses bisnisnya dan mampu mengurangi risiko penyimpangan yang akan terjadi (Irawati, 2017).

\section{c. Penerapan Sistem Informasi Akuntansi (SIA)}

Sistem informasi akuntansi (SIA) memiliki pengertian yaitu sekumpulan komponen/ unit/bagian yang saling terkait satu sama lainnya dalam aktivitas pengumpulan, pemrosesan, penyimpanan, dan pendistrisibusian informasi akuntansi (laporan keuangan) yang digunakan oleh stakeholder dalam mendukung pengambilan keputusan serta pengawasan dalam suatu perusahaan atau organisasi (Lestari, 2020). SIA merupakan suatu sistem dalam suatu organisasi yang mempertemukan kebutuhan pengolahan 
transaksi harian, mendukung operasional, bersifat manajerial maupun kegiatan strategis organisasi serta menyediakan laporan-laporan keuangan yang diperlukan bagi stakeholder, dengan kata lain SIA berperan sebagai teknologi informasi yang membantu pihak manajemen untuk mebuat laporan-laporan yang terkait dengan keuangan atau akuntansi, termasuk laporan-laporan umum lainnya yang mendukung operasional maupun strategi manajemen (Zulfah, 2017).

Tujuan penerapan dari SIA pada entitas perusahaan adalah (Putri, 2020) :

1) Mengamankan harta kekayaan perusahaan

2) Menghasilkan beragam informasi untuk pengambilan keputusan

3) Menghasilkan informasi untuk pihak eksternal

4) Menyediakan data masa lampau untuk penelusuran dan pemeriksaan audit

5) Menghasilkan laporan untuk menyusun dan mengevaluasi anggaran perusahaan

6) Menyediakan informasi yang diperlukan dalam kegiatan perencanaan dan pengendalian.

\section{d. Kompetensi Sumber Daya Manusia (SDM)}

Sumber daya manusia (SDM) merupakan salah satu sumber daya suatu organisasi atau perusahaan memiliki peranan penting dalam pencapaian tujuan organisasi. Kualitas sumber daya manusia menentukan keberhasilan mencapai tujuan organisasi dalam menjalankan fungsi dan tugasnya, sumber daya manusia memiliki peran dominan dan aktif pada setiap aktifitas di dalam organisasi, karena SDM berperan sebagai perencana, pelaku, sekaligus penentu tercapainya tujuan perusahaan atau organisasi (Samsuni, 2017). Kompetensi merupakan karakteristik yang mendasari seseorang dalam mencapai kinerja yang tinggi. Keterampilan (skil) adalah kapasitas yang dibutuhkan untuk melaksanakan suatu rangkaian tugas yang berkembang dari hasil pelatihan dan pengalaman (Kiranayanti, 2016).

Sumber daya manusia merupakan unsur penting dalam pengembangan entitas perusahaan dan sumber daya manusia harus memiliki kompetensi tinggi agar dapat mendukung pencapaian tujuan organisasi dalam hal ini adalah menghasilkan informasi laporan keuangan berkualitas (Pattiasina, 2016). Kompetensi SDM adalah seseorang yang memiliki 3 unsur penting, yaitu 1) keterampilan (skill), 2) pengetahuan (knowledge), dan 3) kemampuan (abilty).

\section{e. Sistem Pengendalian Internal (SPI)}

SPI merupakan proses yang terintegrasi pada suatu kegiatan atau tindakan yang dilakukan secara berulang-ulang baik oleh level manajer maupun level pelaksana untuk memberikan jaminan memadai agar tercapainya tujuan organisasi melalui tindakan yang efektif serta efisien, laporan keuangan yang andal, pengamanan aset perusahaan, serta kepatuhan terhadap peraturan yang berlaku (Tawaqal, 2017). SPI terdiri dari seperangkat prosedur atau kebijakan untuk mengamankan aset atau kekayaan perusahaan dari segala risiko penyalahgunaan, kemudian menjamin ketersediaan informasi laporan keuangan perusahaan yang akurat, serta memastikan bahwa semua kebijakan maupun peraturan perusahaan telah dijalankan oleh seluruh pihak di dalam organisasi atau perusahaan (Putri, 2020). Sedangkan komponen utama dari sistem pengendalian internal terdiri dari 1) lingkungan pengendalian, 2) penilaian risiko, 3) informasi dan komunikasi, serta 4) pemantauan.

\section{Hipotesis}

Berdasarkan latar belakang masalah dan kajian pada landasaan teori, maka penelitian ini menetapkan satu variabel terikat yaitu kualitas laporan keuangan, dua variabel bebas yaitu penerapan sistem informasi akuntansi dan kompetensi sumber daya manusia, serta satu variabel sebagai pemoderasi yaitu sistem pengendalian internal. Kerangka konseptual penelitian yang terbentuk adalah faktor determinan penerapan SIA dan kompetensi SDM berpengaruh terhadap kualitas laporan keuangan dengan penerapan SPI sebagai variabel pemoderasi. Berdasarkan hal tersebut maka model kerangka konseptual atau model penelitian yang terbentuk adalah sebagai berikut: 


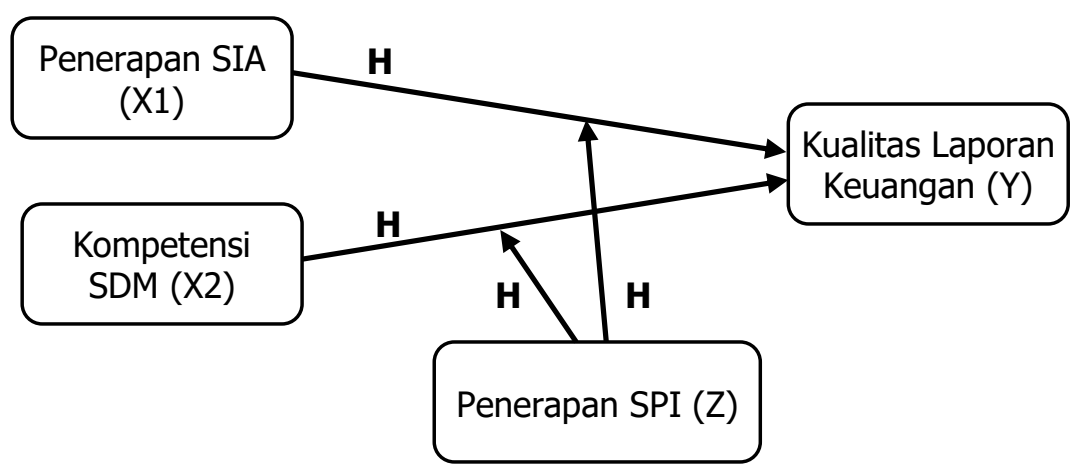

Gambar 1 : Model Penelitian

berikut:

Hipotesis yang dapat dibangun berdasar model penelitian di atas adalah sebagai

\section{a. Penerapan SIA terhadap kualitas laporan keuangan}

Penerapan SIA pada suatu organisasi membantu proses akuntansi yang dimulai dari pencatatan, pengikitisaran dan pelaporan yang berkaitan satu sama lain. Perwujudan penerapan sistem informasi akuntansi, maka pihak pemilik perusahaan beserta pihak manajemen sepakat untuk memberikan laporan keuangan yang berkualitas untuk kepentingan para stakeholder. Untuk menghasilkan laporan keuangan berkualitas, kedua belah pihak juga sepakat untuk untuk menerapkan sistem informasi akuntansi yang modern dan efektif (Zulfah, 2017). Bentuk sistem informasi akuntansi modern adalah pemanfaatan teknologi informasi yang menghasilkan efisiensi dan tingkat efektivitas waktu, sehingga membantu pihak manajemen menyediakan informasi bagi stakeholder dengan akurat dan tepat waktu (Nugroho, 2019).

Penerapan SIA pada perusahaan dapat menghasilkan atau menyajikan laporan keuangan yang berkualitas sesuai kebutuhan stakeholder. Hal ini juga didukung penelitian sebelumnya, yaitu Gusherinsya dkk (2020), Nugroho dkk (2019), dan Zulfah dkk (2017) yang menyatakan bahwa penerapan SIA berpengaruh terhadap kualitas laporan keuangan. Berdasarkan teori stakeholder dan penelitian sebelumnya, maka hipotesis pertama adalah

H1: Penerapan SIA berpengaruh terhadap kualitas laporan leuangan

\section{b. Kompetensi SDM terhadap kualitas laporan keuangan}

Kompetensi SDM merupakan tingkat kemahiran serta kemampuan seseorang atau individu pada suatu entitas perusahaan dalam melaksanakan fungsi-fungsi atau kewenangannya secara efektif dan efisien dalam rangka mencapai tujuan organisasi atau perusahaan (Sudiarti, 2020). Kompetensi sumber daya manusia pada penelitian ini adalah kemampuan personel dalam mencapai kinerja, menghasilkan luaran serta hasil sebagai sasaran aktivitas. Sesuai dengan teori stakeholder, entitas berusaha memenuhi kepentingan stakeholder dengan cara penyediaan sumber daya yang berkualitas. Kompetensi sumber daya manusia dalam bidang akuntansi atau keuangan yang dimiliki perusahaan akan berdampak pada hasil kinerja dan wewenangnya, yaitu menghasilkan laporan keuangan yang efisien, tepat waktu dan akurat.

Hasil penelitian sebelumnya, di mana kompetensi sumber data manusia berpengaruh terhadap kualitas laporan keuangan sudah dilakukan oleh Kiranayanti \& Erawati (2016); Pujanira \& Taman (2017) dan Yendrawati (2013). Hasil tersebut memiliki arti bahwa tingkat kualitas laporan ditentukan oleh tingkat kompetensi sumber daya manusia yang dimiliki entitas perusahaan. Berdasarkan teori stakeholder dan penelitian sebelumnya, maka hipotesis kedua adalah

H2: Kompetensi SDM berpengaruh terhadap kualitas laporan leuangan

c. Penerapan SPI pada hubungan antara penerapan SIA terhadap kualitas laporan keuangan

Sistem pengendalian internal (SPI) penting dilakukan oleh manajemen untuk mengawasi kinerja bawahannya demi keberlangsungan kepentingan stakeholder dalam hal ini laporan keuangan berkualitas (Faishol, 2016). Penerapan SIA memerlukan pedoman teknis dan prosedur penggunannya karena setiap entitas pada perusahaan memiliki kebijakan maupun peraturan yang berbeda (Nurillah, 2014). Penyamaan persepsi dalam penerapan sistem informasi akuntansi penting dilakukan untuk kemudahan pencapaian organisasi. Penyamaan persepsi yang dimaksud misalkan dalam penggunaan akun-akun tertentu atas biaya-biaya yang dikeluarkan. Cara pengendalian internal seperti ini akan 
membantu dan memaksimalkan penerapan sistem informasi akuntansi dalam menyusun laporan keuangan yang berkualitas.

Hasil penelitian sebelumnya di mana variabel penerapan sistem pengendalian internal sebagai variabel moderasi terhadap hubungan variabel penerapan sistem informasi akuntansi terhadap kualitas laporan keuangan sudah dilakukan oleh Tawaqal dkk (2017), Inapty dkk (2016). Berdasarkan teori stakeholder dan penelitian sebelumnya, maka hipotesis ketiga adalah

H3: Penerapan SPI mampu mempengaruhi penerapan SIA terhadap kualitas laporan keuangan

d. Penerapan SPI pada Hubungan Kompetensi SDM Terhadap Kualitas Laporan Keuangan

Sistem pengendalian internal merupakan sekumpulan prosedur dan kebijakan perusahaan untuk mengamankan aset perusahaan dari risiko penyalahgunaan, serta menjamin tersedianya laporan keuangan perusahaan yang akurat, dan memastikan bahwa semua peraturan maupun kebijakan manajemen telah dipatuhi atau dijalankan sebagaimana mestinya oleh semua stakeholder perusahaan. Sumber daya manusia sebagai unsur paling penting dalam organisasi perlu menjadi fokus utama sasaran pengendalian internal manajemen (Putri, 2020).

Kompetensi SDM yang baik ditentukan oleh keterampilan, pengetahuan dan kemampuan yang baik juga. Indikator-indikator tersebut dilengkapi dengan standar operasional kerja yang teratur akan membuat penyusunan laporan keuangan yang berkualitas dengan efektif dan efisien serta sesuai jalur perusahaan (Pattiasina, 2016). Oleh karena itu sistem pengendalian internal yang dilakukan oleh manajemen dapat membantu SDM dalam menyusun laporan keuangan.

Hasil penelitian sebelumnya di mana variabel penerapan SPI sebagai variabel moderasi terhadap hubungan variabel penerapan SIA terhadap kualitas laporan keuangan sudah dilakukan oleh Tawaqal dkk (2017), Inapty dkk (2016). Berdasarkan teori stakeholder dan penelitian sebelumnya, maka hipotesis keempat adalah

H4: Penerapan SPI mampu mempengaruhi kompetensi SDM terhadap kualitas laporan keuangan

\section{Metode Penelitian}

Populasi penelitian ini adalah seluruh karyawan PT X yang berjumlah 450 karyawan. Sampel yang dipakai ialah metode purposive sampling, yaitu pengambilan sampel dengan memakai kriteria yang sudah ditentukan. Kriteria yang digunakan peneliti adalah :

- Responden memiliki latar belakang akuntansi, keuangan, pajak atau disiplin ilmu lainnya yang mendukung penyusunan laporan keuangan.

- Responden penelitian adalah karyawan yang mengoperasikan aplikasi sistem informasi akuntansi sebagai penilaian variabel penerapan sistem informasi akuntansi.

Berdasarkan dua kriteria di atas, maka jumlah sampel pada penelitian adalah sebanyak 94 responden.

\section{a. Alat Penelitian}

Teknik penumpulan data dalam penelitian ini menggunakan angket atau kuesioner yang dilakukan dengan memberi seperangkat daftar pertanyaan kepada responden untuk diisi. Kuesioner dalam penelitian ini menggunakan pernyataan tertutup karena pertanyaan yang tersaji dalam kuesioner adalah pertanyaan alternatif yang jawabannya telah disediakan oleh peneliti dimana pilihan jawaban dalam kuesioner tersebut mengacu pada skala likert 1-5 yang termasuk kedalam jenis skala interval.

Teknik pengambilan data adalah sebuah cara yang dilakukan untuk memperoleh data yang diperlukan dalam sebuah penelitian. Jenis data utama yang diolah pada penelitian ini merupakan data primer. Untuk mendapatkan data yang relevan, peneliti menggunakan teknik pengumpulan data dengan penyebaran kuesioner kepada responden yang memenuhi kriteria penelitian.

\section{b. Metode Analisis}

Metode analisis data yang digunakan pada penelitian ini adalah sebagai berikut

1) Uji Instrumen Kuesioner adalah untuk menguji kelayakan kuesioner yang digunakan dalam penelitian, uji ini terdiri dari uji validitas dan reliabilitas. 
2) Analisis Statistik Deskriptif adalah analisis jawaban kuesioner yang dijawab oleh responden.

3) Uji Asumsi klasik yaitu uji untuk memastikan bahwa data yang digunakan pada tahap penelitian berdistribusi normal. Uji ini terdiri dari uji normalitas, multikolineritas, Heteroskedastisitas

4) Uji Moderatted Regression Analyze (MRA) yaitu analisis uji regresi dengan model variabel pemoderasi. Analisis ini digunakan untuk melihat apakah variabel moderasi (z) mempengaruhi pengaruh antara variabel $x$ (independen/bebas) terhadap variabel $y$ (dependen/terikat)

5) Uji Kebaikan Model yaitu untuk menguji apakah model penelitian secara keseluruhan dengan Uji F dan Koefisien Determinan.

6) Uji Hipotesis dengan menggunakan uji t.

\section{Hasil Penelitian dan Pembahasan}

a. Gambaran Umum Responden

Responden penelitian ini adalah semua karyawan PT X yang bergerak pada bidang transportasi dan kontraktor pertambangan yang berjumlah 450 karyawan. Karyawan tersebar di lima kantor 1 kantor Head Office (HO) dan 4 kantor cabang yaitu Kaliwungu (Kendal), Cilacap, Bogor dan Sebamban (Kalimantan). Sedangkan sampel yang digunakan pada penelitian ini adalah karyawan dengan kriteria memiliki latar belakang pendidikan akuntansi, keuangan, pajak atau disiplin ilmu lainnya yang mendukung penyusunan laporan keuangan, serta karyawan yang mengoperasikan aplikasi sistem informasi akuntansi. Jumlah sampel responden yang memenuhi kriteria di atas adalah sebanyak 94 karyawan.

b. Analisis Kuantitatif Statistik

1) Uji Validitas dan Reabilitas Kuesioner

Uji validitas digunakan untuk mengukur sah atau tidaknya item pertanyaan/ pernyataan yang diajukan di dalam kuesioner. Alat untuk mengukur uji validitas pada penelitian adalah menggunakan uji $r$ (pearson corellation), yaitu membandingkan nilai

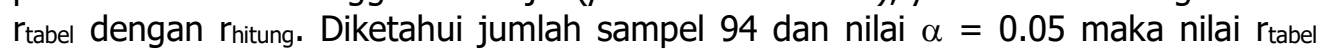
adalah 0,202 . Berikut ini adalah tabel hasil uji validitas item pertanyaan pada kuesioner.

\section{Tabel 1 : Hasil Uji Validitas Variabel Kualitas Laporan Keuangan}

\begin{tabular}{c|c}
\hline $\begin{array}{c}\text { No. } \\
\text { Item }\end{array}$ & $\begin{array}{c}\text { Pearson } \\
\text { Corellation }\end{array}$ \\
\hline 1. & 0,848 \\
2. & 0,671 \\
3. & 0,755 \\
4. & 0,808 \\
5. & 0,768 \\
6. & 0,762 \\
7. & 0,770 \\
8. & 0,785 \\
9. & 0,761 \\
10. & 0,736 \\
11. & 0,710 \\
12. & 0,722 \\
\hline ymer : data primer yang diolah spss, 2021
\end{tabular}

Berdasarkan Tabel 1, diketahui bahwa semua nilai rhitung (pearson corellation) pada setiap item pertanyaan kuesioner lebih besar dari nilai $r_{\text {tabel }}=0,202$. Hal ini artinya bahwa semua item pertanyaan kuesioner variabel Kualitas Laporan Keuangan dinyatakan VALID, dengan kata lain semua item pertanyaan kuesioner tersebut dapat dijadikan indikator untuk mengukur variabel Kualitas Laporan Keuangan. 
Tabel 2 : Hasil Uji Validitas Variabel Penerapan SIA

\begin{tabular}{c|c}
\hline $\begin{array}{c}\text { No. } \\
\text { Item }\end{array}$ & $\begin{array}{c}\text { Pearson } \\
\text { Corellation }\end{array}$ \\
\hline 13. & 0,872 \\
14. & 0,864 \\
15. & 0,894 \\
16. & 0,836 \\
17. & 0,840 \\
18. & 0,893 \\
19. & 0,789 \\
\hline \multicolumn{2}{|c}{ : data primer yang diolah spss, 2021}
\end{tabular}

Berdasarkan Tabel 2, diketahui bahwa semua nilai rhitung (pearson corellation) pada setiap item pertanyaan kuesioner lebih besar dari nilai $r_{\text {tabel }}=0,202$. Hal ini artinya bahwa semua item pertanyaan kuesioner variabel penerapan sistem informasi akuntansi dinyatakan VALID, dengan kata lain semua item pertanyaan kuesioner tersebut dapat dijadikan indikator untuk mengukur variabel Penerapan Sistem Informasi Akuntansi.

Tabel 3 : Hasil Uji Validitas Variabel Kompetensi SDM

\begin{tabular}{c|c}
\hline $\begin{array}{c}\text { No. } \\
\text { Item }\end{array}$ & $\begin{array}{c}\text { Pearson } \\
\text { Corellation }\end{array}$ \\
\hline 20. & 0,684 \\
21. & 0,754 \\
22. & 0,707 \\
23. & 0,790 \\
24. & 0,782 \\
25. & 0,664 \\
26. & 0,690 \\
27. & 0,773 \\
28. & 0,747 \\
29. & 0,755 \\
30. & 0,720 \\
31. & 0,682 \\
\hline
\end{tabular}

Sumber : data primer yang diolah spss, 2021

Berdasarkan Tabel 3, diketahui bahwa semua nilai rhitung (pearson corellation) pada setiap item pertanyaan kuesioner lebih besar dari nilai $r_{\text {tabel }}=0,202$. Hal ini artinya bahwa semua item pertanyaan kuesioner variabel kompetensi SDM dinyatakan VALID, dengan kata lain semua item pertanyaan kuesioner tersebut dapat dijadikan indikator untuk mengukur variabel Kompetensi SDM.

Tabel 4 : Hasil Uji Validitas Variabel Sistem Pengendalian Internal

\begin{tabular}{c|c}
$\begin{array}{c}\text { No. } \\
\text { Item }\end{array}$ & $\begin{array}{c}\text { Pearson } \\
\text { Corellation }\end{array}$ \\
\hline 32. & 0,800 \\
33. & 0,788 \\
34. & 0,809 \\
35. & 0,760 \\
36. & 0,743 \\
37. & 0,818 \\
38. & 0,881 \\
39. & 0,836 \\
40. & 0,846 \\
41. & 0,761 \\
42. & 0,879 \\
43. & 0,773 \\
44. & 0,837 \\
45. & 0,842 \\
46. & 0,821 \\
47. & 0,865 \\
48. & 0,841 \\
39. & 0,789 \\
50. & 0,842 \\
\hline
\end{tabular}

Sumber : data primer yang diolah spss, 2021 
Berdasarkan Tabel 4, diketahui bahwa semua nilai rhitung (pearson corellation) pada setiap item pertanyaan kuesioner lebih besar dari nilai $r_{\text {tabel }}=0,202$. Hal ini artinya bahwa semua item pertanyaan kuesioner variabel Sistem Pengendalian Internal dinyatakan VALID, dengan kata lain semua item pertanyaan kuesioner tersebut dapat dijadikan indikator untuk mengukur variabel Sistem Pengendalian Internal.

Tabel 5 : Ringkasan Hasil Uji Reliabilitas

\begin{tabular}{l|c}
\hline \multicolumn{1}{c|}{ Variabel } & Cronbach Alpha \\
\hline Kualitas Laporan Keuangan (Y) & 0,931 \\
Penerapan Sistem Informasi Akuntansi (X1) & 0,935 \\
Kompetensi Sumber Daya Manusia (X2) & 0,919 \\
Sistem Pengendalian Internal (Z) & 0,973 \\
\hline \multicolumn{2}{c}{ Sumber : data primer yang diolah spss, 2021 }
\end{tabular}

Berdasarkan Tabel 5, diketahui bahwa semua nilai Cronbach A/pha pada setiap indikator variabel kuesioner lebih besar dari 0,7. Hal ini artinya bahwa semua indikator variabel pada kuesioner dinyatakan Reliabel, dengan kata lain semua indikator variabel pada kuesioner tersebut dapat diandalkan.

2) Analisis Regresi Moderasi (Moderated Regression Analyze /MRA)

Alat analisis ini digunakan untuk menguji pengaruh variabel moderasi $(z)$ dalam hubungan variabel independen $(x)$ dengan variabel dependen $(y)$, yaitu melalui uji nilai selisih mutlak. Uji nilai selisih mutlak ini menggunakan nilai standardized score serta selisih dari variabel independen. Pertimbangan mengunakan uji nilai selisih mutlak ini adalah mengurangi dampak multikolinearitas, dampak lainnya adalah akan memperoleh pengaruh yang lebih baik dari variabel babas terhadap variabel terikat. Adapun hasil uji dari MRA dapat dilihat pada Tabel 6 berikut ini.

Tabel 6 : Hasil uji Moderated Regression Analyze

\begin{tabular}{l|r|l}
\hline Variabel & $\begin{array}{r}\text { Unstandardized } \\
\text { Coefficients (B) }\end{array}$ & $\mathbf{t}$ \\
\hline Constant & 15.223 & .001 \\
X1 (SIA) & .395 & .006 \\
X2 (SDM) & .264 & .014 \\
AbsX1_Z & .065 & .473 \\
AbsX2_Z & .238 & .042 \\
\hline
\end{tabular}

Sumber : data primer yang diolah spss, 2021 berikut,

Berdasarkan data Tabel 6, dapat dihasilkan persamaan model regresi sebagai

$$
Y=15,223+0,395 \times 1+0,264 \times 2+0,065 \text { ABSX1_Z + 0,238 ABSX2_Z+e }
$$
Keterangan:

Y $\quad$ : Kualitas Laporan Keuangan

$\mathrm{x} 1 \quad$ : Penerapan SIA

$x 2 \quad$ : Kompetensi SDM

AbsX1_Z : Absolute Penerapan SIA - SPI

AbsX2_Z : Absolute Kompetensi SDM - SPI

e $\quad$ : Standard Error

Persamaan regresi linear di atas dapat dijelaskan sebagai berikut:

- Konstanta (a) $=15,223$, artinya jika koefisien variabel penerapan sistem informasi akuntansi dan kompetensi sumber daya manusia serta interaksinya dengan variabel moderasi sistem pengendalian internal bernilai 0 , maka nilai koefisien variabel kualitas laporan keuangan adalah sebesar 15,223.

- Nilai koefisien variabel Penerapan Sistem Informasi Akuntansi bernilai positif sebesar 0,395 , artinya variabel penerapan sistem informasi akuntansi memiliki arah pengaruh positif terhadap variabel kualitas laporan keuangan. Dan apabila ada penambahan nilai koefisien variabel penerapan sistem informasi akuntansi sebesar 1 satuan maka nilai koefisien variabel kualitas laporan keuangan akan naik sebesar 0,395 satuan. 
- Nilai koefisien variabel kompetensi sumber daya manusia bernilai positif sebesar 0,264, artinya variabel kompetensi SDM pengaruh positif terhadap variabel kualitas laporan keuangan. Apabila ada penambahan nilai koofisien variabel kompetensi sumber daya manusia sebesar 1 satu maka nilai koefisien variabel kualitas laporan keuangan akan naik sebesar 0,264 satuan.

- Nilai koefisien interaksi antara variabel penerapan sistem informasi akuntansi dengan sistem pengendalian internal bernilai positif sebesar 0,065 , artinya interakasi antara variabel penerapan sistem informasi akuntansi dengan penerapan sistem pengendalian internal memiliki arah pengaruh positif. Apabila nilai koefisien variabel interaksi/moderasi penerapan sistem informasi akuntansi dengan penerapan sistem pengendalian internal naik 1 satuan, maka maka akan menambah nilai koefisien variabel kualitas laporan keuangan sebesar 0,065.

- Nilai koefisien interaksi antara variabel kompetensi SDM dengan sistem pengendalian internal bernilai positif sebesar 0,238 , artinya interakasi antara variabel kompetensi SDM dengan penerapan SPI pengaruh positif. Apabila nilai koefisien variabel interaksi/moderasi kompetensi SDM dengan penerapan SPI naik 1 satuan, maka maka akan menambah nilai koefisien variabel kualitas laporan keuangan sebesar 0,238.

3) Uji Kebaikan Model

Penelitian ini menggunakan Uji $\mathrm{F}$ dan Koefisien Determinasi untuk menguji apakah model penelitian ini bisa diteruskan pada tahap pengujian hipotesis dan dikatakan model penelitian yang baik, serta untuk mengetahui seberapa besar variabel independen mempengaruhi variabel dependen. Berikut ini adalah tabel hasil uji F dan Koefisien Determinasi.

Tabel 7 : Tabel Hasil Uji F dan Koefisien Determinasi

\begin{tabular}{cccc}
\hline \multicolumn{2}{c}{ Uji F } & \multicolumn{2}{c}{ Koefisien Determinasi } \\
F & Sign & R Square & Adjusted R Square \\
\hline 19,919 & 0.000 & 0,304 & 0,289 \\
\hline
\end{tabular}

Sumber : data primer yang diolah spss, 2021

Berdasarkan Tabel 7 nilai signifikansi di bawah 0,05 yaitu sebesar 0,000. Hal ini berarti bahwa semua variabel bebas yaitu penerapan SIA dan kompetensi SDM serta interaksi keduanya dengan variabel penerapan SPI secara bersama-sama memiliki pengaruh signifikan terhadap kualitas laporan keuangan.

Nilai Adjusted $R$ Square sebesar 0,289, artinya variabel kualitas laporan keuangan dan variabel kompetensi sumber daya manusia yang dimoderasi variabel sistem pengendalian internal memberikan kontribusi pengaruh variabel kualitas laporan keuangan sebesar $28,90 \%$, sedangkan $71,10 \%$ variabel kualitas laporan keuangan dipengaruhi variabel-variabel lainnya di luar model penelitian ini.

4) Uji Hipotesis

Uji hipotesis pada penelitian ini menggunakan Uji t, uji signifikansi parsial yang menguji hipotesis pengaruh variabel independen dan dependen secara parsial. Berdasarkan Tabel 6, hasil uji hipotesis pada penelitian ini adalah sebagai berikut.

Tabel 8 : Ringkasan Hasil Uji Hipotesis

\begin{tabular}{|c|l|c|c|}
\hline & \multicolumn{1}{|c|}{ Hipotesis } & Sign. & Hasil \\
\hline H1 & $\begin{array}{l}\text { Penerapan SIA berpengaruh signifikan terhadap kualitas laporan } \\
\text { keuangan }\end{array}$ & 0,006 & Diterima \\
\hline H2 & $\begin{array}{l}\text { Kompetensi SDM berpengaruh signifikan terhadap kualitas laporan } \\
\text { keuangan }\end{array}$ & 0,014 & Diterima \\
\hline H3 & $\begin{array}{l}\text { Penerapan SPI tidak mampu mempengaruhi penerapan SIA } \\
\text { terhadap kualitas laporan keuangan }\end{array}$ & 0,473 & Ditolak \\
\hline H4 & $\begin{array}{l}\text { Penerapan SPI mampu mempengaruhi kompetensi SDM terhadap } \\
\text { kualitas laporan keuangan }\end{array}$ & 0,042 & Diterima \\
\hline
\end{tabular}

Sumber : data primer yang diolah spss, 2021 


\section{c. Analisis Pembahasan}

\section{1) Penerapan SIA Terhadap Kualitas Laporan Keuangan}

Hasil jawaban responden menunjukkan pada taraf setuju yang artinya responden mempunyai presepsi bahwa penerapan sistem informasi akuntansi di PT X sudah baik. PT. X sebagai entitas bisnis berpandangan bahwa penerapan sistem informasi akuntansi akan mempermudah karyawan dalam mencatat transaksi sampai dengan pembuatan laporan keuangan. Laporan keuangan yang dihasilkan oleh SIA tersebut dinilai lebih mudah dipahami dan lebih dicepat untuk diakses, yang pada akhirnya kualitas laporan keuangan yang disajikan lebih baik. Manajemen PT X menggunakan aplikasi ACCURATE untuk memenuhi kepentingan stakeholder tersebut dalam hal penyediaan laporan keuangan yang berkualitas.

Berdasarkan hasil pengujian hipotesis, menunjukkan bahwa penerapan sistem informasi akuntansi berpengaruh signifikan terhadap kualitas laporan keuangan. Diketahui nilai $\beta=0,395$ dan nilai $\alpha=0,006$, di mana nilai signifikansi dibawah 0,05 yang berarti hipotesis H1 diterima. Dengan kata lain apabila penerapan SIA yang diterapkan oleh PT X semakin baik, maka kualitas laporan keuangan yang dihasilkan juga akan semakin baik.

Hasil penelitian ini yang menyatakan bahwa penerapan SAI berpengaruh terhadap kualitas laporan keuangan, hal ini sejalan dengan hasil penelitian sebelumnya yaitu dari Gusherinsya \& Samukri (2020); Nugroho \& Setyowati, (2019) dan Prasisca et al., (2012). Penerapan sistem informasi akuntansi mendampingi manajemen dalam menciptakan laporan keangan yang berkualitas. Bantuan teknologi akuntansi dianggap mempermudah kinerja manajemen, karena cara kinerja menjadi tertata dan terciptanya efisiensi waktu bekerja. Penerapan SIA merupakan salah satu strategi entitas pada penciptaan keuangan berkualitas yang merupakan kepentingan dari stakeholder.

\section{2) Kompetensi SDM Terhadap Kualitas Laporan Keuangan}

Jawaban responden mengenai presepsi pengaruh kompetensi sumber daya manusia terhadap kualitas laporan keuangan menunjukkan pada taraf mendekati setuju, artinya karyawan PT X memiliki kompetensi tentang akuntansi yang baik. Berdasarkan data deskriptif semua responden pada penelitian ini memiliki latar belakang pendidikan akuntansi atau keuangan. Oleh karena itu, hasil penelitian menyatakan bahwa kompetensi sumber daya manusia di PT X cukup baik, yaitu memiliki kompetensi atau menguasai siklus akuntansi dengan baik mulai dari pencatatan sampai dengan pelaporan.

Berdasarkan hasil uji hipotesis pada penelitian ini menunjukkan bahwa kompetensi sumber daya manusia berpengaruh signifikan terhadap kualitas laporan keuangan. Hal ini bisa dilihat dari nilai unstandarized coefficient beta sebesar 0,264 dan signifikansi 0,014, artinya nilai signifikansi dibawah 0,05 yang berarti hipotesis $\mathrm{H} 2$ diterima. Dengan kata lain apabila variabel kompetensi sumber daya manusia yang dimiliki PT X semakin baik, maka variabel kualitas laporan keuangan yang dihasilkan juga akan semakin baik. Manajemen PT X bersama komisaris utama memiliki kesamaan pandangan untuk memiliki kepentingan atas laporan keuangan, oleh karena itu pihak manajemen memaksimalkan karyawan yang memiliki kompetensi tinggi untuk memenuhi kepentingan stakeholder tersebut.

Hasil penelitian ini menyatakan bahwa kompetensi sumber daya manusia berpengaruh signifikan terhadap kualitas laporan keuangan. Hasil ini sejalan dengan hasil penelitian dari Kiranayanti \& Erawati (2016); Pujanira \& Taman (2017) dan Yendrawati (2013). Hasil tersebut memiliki arti bahwa kualitas laporan dipengaruhi oleh kompetensi sumber daya manusia yang dimiliki entitas. Sesuai dengan teori stakeholder, entitas berusaha memenuhi kepentingan stakeholder yaitu penyajian laporan keuangan berkualitas dengan cara penyediaan SDM berkualitas juga.

3) Penerapan SPI Memoderasi Pengaruh Penerapan SIA Terhadap Kualitas Laporan Keuangan

Jawaban responden mengenai variabel penerapan sistem pengendalian internal menunjukkan pada taraf setuju yang artinya karyawan PT $\mathrm{X}$ berpandangan telah dikontrol dengan baik atau dengan kata lain penerapan sistem pengendalian internal telah berjalan dengan optimal. Tetapi kaitannya dalam memoderasi pengaruh penerapan sistem informasi akuntansi terhadap kualitas laporan keuangan ditemukan tidak berpengaruh. 
Berdasarkan hasil uji hipotesis pada penelitian ini menunjukkan bahwa variabel sistem pengendalian internal tidak mampu mempengaruhi penerapan sistem informasi akuntansi terhadap kualitas laporan keuangan. Hal ini bisa dilihat dari nilai unstandarized coefficient beta sebesar 0,065 dan nilai signifikansi sebesar 0,473 berada di atas taraf signifikansi yaitu 0,05 berarti hipotesis ditolak. Hal ini berarti penerapan sistem pengendalian internal tidak mempengaruhi penerapan sistem informasi akuntansi dalam rangka penciptaan laporan keuangan yang berkualitas.

Sistem pengendalian internal penting dilakukan oleh manajemen untuk mengawasi kinerja bawahannya demi keberlangsungan kepentingan stakeholder dalam hal ini laporan keuangan yang berkualitas. Tetapi pada penelitian ini sistem pengendalian internal tidak mempengaruhi penerapan sistem informasi akuntansi terhadap kualitas laporan keuangan. Selain itu implementasi sistem informasi akuntansi yaitu aplikasi ACCURATE sudah memiliki sistem pengendalian dalam operasionalnya, di mana pengguna aplikasi hanya mengikuti konten yang tersedia dan tinggal menjalankan, sehingga sistem pengendalian internal yang tersedia telah cukup berjalan dengan baik.

4) Penerapan SPI Memoderasi Pengaruh Kompetensi SDM Terhadap Kualitas Laporan Keuangan

Jawaban responden mengenai variabel sistem pengendalian internal menunjukkan pada taraf setuju yang artinya karyawan PT X memiliki presepsi telah dikontrol dengan baik atau dengan kata lain penerapan sistem pengendalian internal telah berjalan dengan optimal. Kaitannya dalam memoderasi pengaruh kompetensi sumber daya manusia terhadap kualitas laporan keuangan memiliki pengaruh yang signifikan. Penerapan sistem pengendalian internal berhasil mengontrol karyawan dalam melaksanakan tugas dan kewajibannya dalam hal ini membuat laporan keuangan yang berkualitas.

Berdasarkan hasil uji hipotesis pada penelitian ini menunjukkan bahwa variabel sistem pengendalian internal mampu mempengaruhi variabel kompetensi sumber daya manusia terhadap variabel kualitas laporan keuangan. Hal ini bisa dilihat dari nilai unstandarized coefficient beta sebesar 0,238 dan nilai signifikansi sebesar 0,042 yang berada di bawah taraf signifikansi yaitu 0,05 yang berarti hipotesis diterima. Hal ini berarti penerapan sistem pengendalian internal mempengaruhi kompetensi sumber daya manusia dalam membuat laporan keuangan yang berkualitas. Karyawan PT X dengan kompetensi yang dimilikinya akan semakin baik dalam membuat laporan keuangan apabila pihak manajemen menerapkan sistem pengendalian internal yang lebih baik.

Sumber daya manusia sebagai salah satu stakeholer memiliki peranan penting dalam menjalankan aktivitas perusahaan termasuk dalam membuat laporan keuangan yang berkualitas. Oleh karena itu penerapan sistem pengendalian internal yang optimal akan berdampakan pada sumber daya manusia yang kompeten untuk semakin baik dalam membuat laporan keuangan yang berkualitas. Hasil dari interaksi tersebut adalah terjadinya kenaikan hasil audit di tahun 2019 yaitu Wajar Dengan Pengecualian (WDP) yang 2 (dua) tahun sebelumnya yaitu tahun 2017 dan 2018 mendapatkan opini tidak wajar. Hal ini membuktikan bahwa sistem pengendalian internal benar-benar mempengaruhi komptensi sumber daya manusia terhadap kualitas laporan keuangan.

\section{Kesimpulan dan Saran}

a. Kesimpulan

Berdasarkan hasil pengujian statistik beserta pembahasan analisisnya, maka kesimpulan yang diperoleh dari penelitian ini adalah penerapan sistem informasi akuntansi dan kompetensi sumber daya manusia berpengaruh signifikan terhadap kualitas laporan keuangan. Demikian juga halnya penerapan sistem pengendalian internal mampu mempengaruhi dan memoderasi kompetensi sumber daya manusia untuk mempengaruhi kualitas laporan keuangan. Namun hasil yang berbeda ketika sistem pengendalian internal tidak mampu mempengaruhi atau memoderasi penerapan sistem informasi akuntansi untuk mempengaruhi kualitas laporan keuangan. 


\section{b. Saran}

Berdasarkan hasil temuan pada penelitian ini serta jawaban dari responden, peneliti memberikan saran sebagai berikut, 1) mengupdate penerapan sistem informasi akuntansi dengan memperbaharui teknologi aplikasi akuntansi berbasis cloud yang terintegrasi, 2) menerapkan sistem pengendalian internal berbasis teknologi untuk mengantisipasi risiko dampak dari penerapan teknologi baru aplikasi akuntansi, 3) meningkatkan kompetensi teknologi informasi bagi sumber daya manusia yang terlibat dalam penyusunan laporan keuangan, serta 4) bagi peneliti selanjutnya untuk memperluas variabel-variabel faktor determinan sehingga menghasilkan model penelitian yang lebih baik lagi.

\section{Daftar Pustaka}

Dita, M. A., \& Putra, I. W. (2016). Pengaruh Penerapan Sistem Informasi Akuntansi Terhadap Kinerja Karyawan Dengan Integritas Karyawan Sebagai Variabel Moderasi. E-Jurnal Akuntansi Universitas Udayana, 15(1), 614-640.

Djanegara, M. S. (2017). Pengaruh Kualitas Audit Terhadap Kualitas Laporan Keuangan Pemerintah Daerah. Jurnal Akuntansi, XXI(03), 461-483..

Faishol, A. (2016). Pengaruh Sistem Pengendalian Intern Terhadap Kualitas Laporan Keuangan (Studi Kasus Pada Satuan Kerja Perangkat Daerah Pemerintah Kabupaten Lamongan). Jurnal Penelitian Ekonomi Dan Akuntansi, I(3), 205-212.

Gusherinsya, R., \& Samukri. (2020). Pengaruh Penerapan Sistem Informasi Akuntansi Terhadap Kualitas Laporan Keuangan. Jurnal Akuntansi, 9(1), 58-68. Retrieved from http://ejournal.stiemj.ac.id/index.php/akuntansi

Hamdani. (2016). Good Corporate Governance: Tinjauan Etika dalam Praktik Bisnis (Pertama). Jakarta: Mitra Wacana Media.

Inapty, M. A. F. B. A., \& Martiningsih, R. S. P. (2016). Pengaruh Penerapan Standar Akuntansi Pemerintah, Kompetensi Aparatur dan Peran Audit Internal Terhadap Kualitas Laporan Keuangan. Jurnal IImu Akuntansi, 9(April), 27-42. https://doi.org/10.15408/akt.v9i1.3583

Irawati, Salju, \& Hapid. (2017). Pengaruh Penggunaan Sistem Informasi Manajemen Terhadap Kualitas Laporan Keuangan Pada PT. Telkom Kota Palopo. Jurnal Manajemen, 3(2), 6-12.

Kiranayanti, I. A. E., \& Erawati, N. M. A. (2016). Pengaruh Sumber Daya Manusia, Sistem Pengendalian Intern, Pemahaman Basis Akrual Terhadap kualitas Laporan Keuangan Daerah. E-Jurnal Akuntansi Universitas Udayana, 16(2), 1290-1318.

Lestari, N. L. W. T., \& Dewi, N. N. S. R. T. (2020). Pengaruh Pemahaman Akuntansi, Pemanfaatan Sistem Informasi Akuntansi dan Sistem Pengendalian Intern Terhadap Kualitas Laporan Keuangan. Jurnal Krisna, 11(2), 170-178.

Lestari, W. S., \& Priyadi, M. P. (2017). Faktor-faktor Yang Mempengaruhi Kualitas Laporan Keuangan Berbasis SAK-ETAP Pada UMKM. Jurnal IImu dan Riset Akuntansi, 6(10), 1-20.

Mandaika, Y., \& Salim, H. (2013). Pengaruh Ukuran Perusahaan, Kinerja Keuangan, Tipe Industri dan Finnacial Leverage Terhadap Pengungkapan Corporate Social Responsbility. Jurnal Akuntansi, 8(2), 181-201.

Munawarah, I. Y. (2017). Kajian Teori Stakeholders Terkait Perlindungan Hukum Bagi Pemegang Saham Minoritas. Jurnal IImu Hukum The Juris, I(1), 15-45.

Nugroho, F. A., \& Setyowati, W. (2019). Pengaruh Komitmen Organisasional, Sistem Informasi Akuntansi, Dan Peran Audit Internal Terhadap Kualitas Laporan Keuangan. Journal of Economics and Banking, 1(2), 125-134.

Nurillah, A. S. (2014). Pengaruh Kompetensi Sumber Daya Manusia, Penerapan Sistem Akuntansi Keuangan Daerah, Pemanfaatan Teknologi Informasi dan Sistem Pengednalian Internal Terhadap Kualitas Laporan Keuangan Pemerintah Daerah (Skripsi). Semarang: Universitas Diponegoro.

Pattiasina, M., Roring, M., \& Rumawas, W. (2016). Pengaruh Kompetensi Sumber Daya Manusia Terhadap Kinerja Karyawan PT.Bank. Jurnal Administrasi Bisnis, 4(2), 1-6. 
Pujanira, P., \& Taman, A. (2017). Pengaruh Kompetensi Sumber Daya Manusia, Penerapan Standar Akuntansi Pemerintahan, dan Penerapan Sistem Akuntansi Keuangan Daerah Terhadap Kualitas Laporan Keuangan Pemerintah Daerah Provinsi DIY. Jurnal Nominal, VI(4), 14-29.

Putri, D. A., Mawardi, M. C., \& Hariri. (2020). Pengaruh Sistem Pengendalian Internal dan Sistem Informasi Akuntansi Terhadap Kualitas Laporan Keuanga (Studi Empiris Pada SKPD Kabupaten Lombok Tengah). Jurnal E-JRA, 09(03), 49-61.

Putri, P. A. Y., \& Endiana, I. D. M. (2020). Pengaruh Sistem Informasi Akuntansi dan Sistem Pengendalian Internal Terhadap Kinerja Perusahaan (Studi Kasus pada Koperasi di Kecamatan Payangan). Jurnal Krisna, 11(2), 179-189.

Putri, W. S., \& Hendarsyah, D. (2020). Pengaruh Sistem Pengendalian Internal Terhadap Penerapan Sistem Komputerisasi Haji Terpadu (SISKOHAT). Jurnal Inovasi Bisnis, 8, 52-58.

Rokhlinasari, S. (2015). Teori-teori dalam Pengungkapan Informasi Corporate Social Responbility Perbankan. Al-Amwal Jurnal Kajian Ekonomi Dan Perbankan Syariah, 7(1), 1-11. https://doi.org/10.24235/amwal.v7i1.217

Samsuni. (2017). Manajemen Sumber Daya Manusia. Jurnal Al-Falah, 17(31), 113-124.

Sarwani, Nailiah, R., \& Latif, D. M. (2019). Pengaruh Kualitas Laporan Keuangan Terhadap Tingkat Penerimaan Kredit Serta Implementasi Sak Etap. Jurnal Riset Akuntansi Keuangan, 4(1), 1129.

Siregar, B. (2015). Akuntansi Sektor Publik (Pertama). Yogyakarta: Unit Peneribit dan Percetakan STIM YKPN.

Sudiarti, N. W., \& Juliarsa, G. (2020). Pengaruh Kompetensi Sumber Daya Manusia dan Locus of Contro/Terhadap Kualitas Laporan Keuangan LPD. E-Jurnal Akuntansi Universitas Udayana, 30(7), 1725-1737. Retrieved from https://ojs.unud.ac.id/index.php/Akuntansi/index 1725

Syoftia, E., Puspa, D. F., \& Ethika. (2016). Pengaruh Karakteristik Pemerintah Daerah, Opini Audit terhadap Tingkat Pengungkapan Wajib dalam Laporan Keuangan Pemerintah Daerah (Study pada LKPD Kabupaten/Kota Provinsi Sumatera Barat). Jurnal Fakultas Ekonomi, 9(1), 1-14.

Tawaqal, I., \& Suparno. (2017). Pengaruh Penerapan Sistem Informasi Akuntansi, Sistem Pengendalian Internal dan Kompetensi Sumber Daya Manusia Terhadap Kualitas Laporan Keuangan SKPD di Pemerintah Kota Banda Aceh. Jurnal Ilmiah Mahasiswa Ekonomi Akuntansi (JIMEKA0, 2(4), 125-135.

Yendrawati, R. (2013). Pengaruh Sistem Pengendalian Intern dan Kapasitas Sumber Daya Manusia Terhadap Kualitas Informasi Laporan Keuangan dengan Faktor Eksternal Sebagai Variabel Moderating. Junal JAAI, 17(2), 166-175.

Zulfah, I., Wahyuni, S., \& Nurfaza, A. (2017). Pengaruh Sistem Informasi Akuntansi Terhadap Kualitas Laporan Keuangan pada SKPD Kabupaten Aceh Utara. Jurnal Akuntansi dan Pembangunan, 3(2), 46-57. 